\title{
Use of polyethylene glycol to improve the utilisation of leguminous leaf meals in pigs: A review
}

\author{
V. A Hlatini ${ }^{1}$, C. N Ncobela ${ }^{1,2}$, T. J. Zindove ${ }^{3}$ \& M. Chimonyo ${ }^{1 \#}$ \\ ${ }^{1}$ Animal and Poultry Science, School of Agricultural, Earth and Environmental Sciences, University of KwaZulu-Natal, P \\ bag X01 Scottsville 3209, Pietermaritzburg, South Africa \\ ${ }^{2}$ Current address: Agricultural Research Council-Animal Production Institute (Nutrition Building), Private Bag X2, Irene \\ 0062, South Africa \\ ${ }^{3}$ Department of Animal Science, Faculty of Agriculture and Environmental Science, Bindura University of Science \\ Education, Private Bag 1020, Bindura, Zimbabwe
}

(Received 6 October 2017; Accepted 14 February 2018; First published online 6 April 2018)

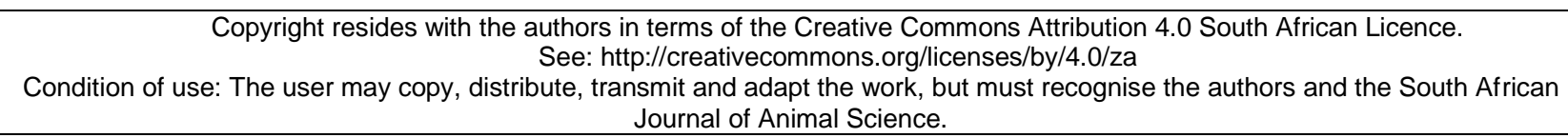

\begin{abstract}
The use of leguminous leaf meal as feed ingredients for pigs needs to be intensified and improved. Leguminous trees and shrubs are valuable sources of protein, amino acids, and dietary fibre for pigs. Leguminous leaf meals are abundant in the tropical regions and their use as alternate protein-rich feed ingredients for pigs is promising. In tropics, climate change and vegetation management practices have certainly increased the availability of shrub legumes compared to grasses. There is, therefore, a need to resort on harnessing abundant and cheap feed resources to cope with environmental changes and rise of feed prices. Leguminous leaf meals are invaluable feed ingredients for pigs because of their relatively high crude protein and they are highly available. The leguminous leaves also thrive in, and tolerate, adverse climatic and soil conditions. However, their utilisation is limited by presence of polyphenolic compounds, particularly condensed tannins that inhibit their efficient use by pigs. Other challenges for the utilisation of legume-based leaf meal diets are the presence of thorns and high fibre content. If leguminous leaf meals are included in the diet beyond optimum levels, polyphenolic compounds can suppress appetite, promote feed refusal, reduce digestibility, and can induce toxicity in pigs. This warrants investigation on the use of tanninbinding agents (TBA) to improve nutrient utilisation of leguminous leaf meal-containing diets fed to pigs. The inclusion level of polyethylene glycol (PEG) in livestock diets has a huge potential to neutralise negative effects of undesirable polyphenolic compounds. Therefore, the current review aimed to assess the potential of PEG to inactivate tannin and amount of PEG to include for optimum pig performance.
\end{abstract}

Keywords: Leguminous leaf meals, performance, pigs, polyethylene glycol, polyphenolic compounds

\#Corresponding author: chimonyo@ukzn.ac.za

\section{Introduction}

Pork production is on the increase due to rising demand for pork products; as a result of human population growth and it being one of the richest dietary sources of protein. The growing awareness about the health benefits of white meat is also increasing the demand for pork. Increase in pork production has resulted in increased demand for feed concentrates. This has resulted in a rising demand for cereal grains for feed. The pig industry uses nearly one-third of the global cereal harvest (Steinfeld \& Opio, 2010). The increased demand for cereal grains for feed, coupled with competition from human consumption, puts pressure on the production of conventional legumes, such as soybeans. Consequently, costs of cereal grains for food and feed are high. As a result, the use of conventional protein sources is disadvantageous because they are expensive. Thus, the use of non-conventional protein-rich feed ingredients for feeding pigs has been gaining ground (Khanyile et al., 2014; Mlambo et al., 2015). This eases pressure on grain legumes and animal protein sources. The use of leguminous leaves also expands the spectrum of feed resources available for pigs. Many leguminous trees have shown potential to be suitable alternative feedstuffs that can 
be used in pig rations as protein sources. These species include Vachellia species viz. karroo, tortilis, nilotica, anguistissima and nigrescens, Leucaena leucocephala, Calliandra calothyrsus, Gliricidia sepium, Leucaena diversifolia, Leucaena pallida, Sechium edule, Psophocarpus scandens, Vigna unguiculata, Sesbania sesban, Entada abyssinica and Tephrosia bracteolate (Halimani et al., 2007; Mapiye et al., 2011; Bhat et al., 2013; Khanyile et al., 2014; Woyengo et al., 2014). Leguminous leaves have high levels of proteins, amino acids, minerals, vitamins, dietary fibre, energy, lipids, and carotenoids, and possess antimicrobial and antioxidant properties, which are essential in pig production efficiency (Halimani et al., 2005; Khanyile et al., 2014; Mlambo et al., 2015). The high crude protein content found in these species could be of benefit to pig nutritionists to ensure least cost formulation of diets with the aim to replace commercial protein sources such as soybean in pig diets.

In addition to their having high protein and mineral contents (Barakat et al., 2013; Woyengo et al., 2014), leguminous trees and shrubs are potential alternative livestock feeds because of their abundance and reliance. Legumes have been the most important encroaching plant species that suppresses the palatability of grass in Southern Africa (Munyati et al., 2013). They contain high crude protein (CP) content ranging from $103-306 \mathrm{~g} / \mathrm{kg} \mathrm{DM}$, amino acid contents, as well as favourable mineral concentration such as calcium (0.4 $0.39 \%$ ), magnesium (0.13-01.37\%), and potassium (0.41 - 0.35\%) (Halimani et al., 2007; Gebeyew et al., 2015; Kambashi et al., 2016). One of the major drawbacks to the use of leguminous leaf meals as protein sources in animal diets is the presence of anti-nutritive factors. The physical and chemical properties of the leguminous meals vary with their species. Khanyile et al. (2014) characterized the nutritional and physical composition of Vachellia species and found that Vachellia tortilis has higher CP content, low water holding capacity, moderate levels of capacity of swell and reasonable condensed tannins compared to $V$. robusta, $V$ xanthophloeoe, and V. nigrescens (Khanyile et al., 2014). Condensed tannins are the major anti-nutritional factor found in the leguminous leaf meals. Condensed tannins inhibit digestion in pigs by binding to proteins in the leguminous meals and, thus, making them difficult to digest. The condensed tannins also interfere with protein absorption and digestive enzymes. It is important to devise cost-effective feeding strategies for leguminous leaf meals to intensify production of leguminous leaves (Mapiye et al., 2011). To enhance digestibility, utilisation, and absorption of nutrients in leguminous leaf meals, there is a need to explore the benefits of incorporating exogenous tannin-binding agents in the diets. Common tannin-binding agents include polyethylene glycol (PEG) and polyvinyl pyrrolidone (PVP). The PEG has been reported to be more effective than PVP in reducing the detrimental effects of polyphenolic compounds in sheep (Ghandour et al. 2014) and broilers (Mansoori \& Acamovic 2007). In goats, PEG does not affect digestion processes and growth performance (Motubatse et al. 2008; Mantz et al. 2009). There is no collective information on the impact of PEG on the performance of pigs. The current review assesses the potential and extent to which PEG could be included in the diet to improve the utilisation of high tannin diets by pigs.

\section{Indigenous legume plants in Southern Africa}

Legume trees are widely dispersed throughout the savannah and dry zones of Africa and are indigenous to semi-arid regions of Africa and Middle East (Wahbi et al., 2013). In Africa, at least $75 \%$ of the trees and shrubs are leguminous (Abule et al., 2007). The composition and distribution of indigenous fodder trees and shrubs vary according to place of origin and natural environmental conditions where they grow naturally. Ward et al. (2014) reported that high availability of woody vegetation is associated with increasing ambient temperatures. The leguminous species are widely distributed and dominant throughout Southern Africa in diverse habitats. Table 1 shows the dominant legume and main encroaching species in Southern Africa. The availability and domination of these leguminous leaves vary with location (Table 1).

These Southern African trees and shrubs are causing bush encroachment that negatively affects the grazing capacity including veld condition leading to reduced forage for grazers. The legume leaves have not been fully exploited as a protein source in pig diets due to anti-nutritional factors. Generally, legume tree leaves contain high amounts of condensed tannins and fibre content. The nutrient composition of legume trees varies with species, soil condition, season, and stage of leaf growth (Nyamukanza \& Scogings, 2008), harvesting and post-harvesting techniques and/or conditions. Earlier reports revealed that leguminous leaf meals are a good source of protein for pigs (Halimani et al., 2005; Khanyile et al., 2014; Ndou et al., 2015; Kambashi et al., 2016). Knowledge on chemical composition and physical properties of leguminous leaf meals is relevant in designing formulation strategies to ensure that anti-nutritional factors do not constrain pig performance. Tables 2 and 3 illustrate the physicochemical and amino acid composition of some selected common legumes in the tropics. 
Table 1 Distribution of species across selected countries in Southern Africa

\begin{tabular}{ll}
\hline Country & Dominant/Encroaching species \\
\hline Tanzania & Vachellia tortilis, Cappeins tomentosa \\
Namibia & Sengelia mellifera, Sengelia. erubscen, Vachellia tortilis, Dichrostachys cinerea \\
Swaziland & Dichrostachys cinerea \\
Botswana & Vachellia tortilis, Sengelia erbubsen, Vachellia fleckii, Salvia mellifera, Dichrostachys \\
Zimbabwe & Cinerea, Grewia flawa, Termina sericea, Arisaema erubscens \\
& Vachellia borleae, Vachellia karroo, Colophospermum mopane, Vachellia nilotica \\
South Africa & Colophospermum mopane, Vachellia tortilis, Vachellia nilotica, Sengelia mellifera, \\
& Euchellia karroo, Dichrostachys cinerea, Vachellia ataxacauntha, Scutia myrtina, \\
\end{tabular}

Source: O'Connor et al. (2014)

\section{Role of legume trees in livestock production}

Legume tress constitute of leaves that are used as protein-rich feed ingredients and partly fibre for cattle, sheep, and goats. They are also appreciated as a source of amino acid and desirable tannins. Mueller-Harvey (2006) reported that tannins found in feeds such as fodder, legumes, browse leaves, fruits and Vachellia species could improve animal welfare as an anthelmintic. Proanthocyanidins may have direct effects on gastrointestinal parasites by reducing the number of eggs hatching, reducing the rate of larval development and decreasing the mobility of larvae (Min \& Hart, 2003). Leguminous species are widely distributed and abundant, making it an ideal ingredient in pig feeds. Some ruminants can counter the protein binding effects of tannins by releasing condensed tannins binding salivary proteins (Naumann et al., 2017).

\section{Challenges associated with utilisation of leguminous trees}

Despite high nutritional composition of leguminous tree leaves, their utilisation in livestock feeding is hampered by high dietary fibre content and polyphenolics, such as tannins. Some of the leguminous trees have thorns as a defense mechanism against herbivores (Mapiye et al., 2011). The density and longevity of thorns are the factors that affect the intake of thorned leguminous trees species. In pig production, the removal of thorns promotes feed consumption (Woyengo et al., 2014).

Thorns can be removed by cutting the small branches and sun-air-drying them for 2 - 4 days, prior to collecting only leaves that are shaken off the branches and used in pig feeding. However, there is a need to develop machinery to replace the use of hands if utilization is to be done at commercial level. The high dietary fibre content is also known to affect the maximum utilisation of leguminous leaves (Khanyile et al., 2015; Ndou et al., 2015a). The high fibre content tends to affect feed intake, the digestibility of organic matter and the net energy in feed. The chemical composition and structure of plants differ with fibre source. The extent of fibre digestibility depends predominantly on the source of fibre and to a lesser extent on amount of fibre in the diet (Philips et al., 2008). Undesired levels of fibre content can be suppressed by ensiling legume species and use of enzyme inoculants to hydrolyze dietary fibre. Commercial pig breeds can consume up to $4 \%$ dietary fibre in the diet (which promotes peristalsis) without affecting voluntary feed intake (Marten et al., 2013).

Although legume trees have high $\mathrm{CP}$ contents, they also possess natural-occurring polyphenolic compounds (Rubanza et al., 2006; Mlambo et al., 2015). Polyphenolic compounds have a molecular weight greater than 500 and have the ability to bind and precipitate protein (Makkar, 2003; Tufarelli et al., 2017). The binding strength of tannins-protein complexes is 151 determined by the molecular weight, tertiary structure, isoelectric point, and compatibility of binding sites (Silanikove et al., 2001). Polyphenolic compounds are found in almost any part of the plant and in different plant tissues. They are present in the seed, roots, stem, leaf and bud and are associated with defense role against disease, microbial infestation and predation. Some of polyphenols may reduce nutrient intake and digestibility by shielding nutrients (Ashok \& Upadhayaya, 2012).

Polyphenolics are divided into hydrolysable and condensed forms (Figure 1). A central carbohydrate core containing various phenolic carboxylic acids such as gallic acid, ellagic acid and hexahydroxydiohenic acid (Ashok \& Upadhayaya, 2012) characterizes hydrolysable polyphenolics. Acids, alkali or some enzymes easily hydrolyse these polyphenolics. Hydrolysable phenolics are present in cereals and/or legumes. As a result, they are associated with positive impact on animal nutrition (Benrick, 2002). When these polyphenolics are hydrolysed, gallic or epigallic and sugar are formed. On the other hand, condensed 
Table 2 Chemical composition of selected common legumes ( $\mathrm{g} / \mathrm{kg} \mathrm{DM}$ )

\begin{tabular}{|c|c|c|c|c|c|c|c|c|c|c|c|c|c|}
\hline & DM & $\mathrm{CP}$ & CF & NDF & ADF & EE & Ash & NDinsolN & AdinsolN & CT & WHC & sc & AD lignin \\
\hline \multicolumn{14}{|c|}{ Non-conventional legumes } \\
\hline V. nilotica & 947 & 198 & - & 399 & 227 & 32.7 & 56.5 & 399 & 227 & 67.7 & 6.44 & 4.57 & - \\
\hline V. karroo & 922 & 154 & 119 & 450 & 300 & - & 110 & - & - & 31.3 & - & - & - \\
\hline V. tortilis & 944 & 218 & - & 494 & 298 & 40.1 & 65.0 & 494 & 298 & 51.5 & 6.06 & 4.78 & - \\
\hline V. nigrescens & 938 & 178 & - & 630 & 477 & 30.0 & 78.3 & 630 & 477 & 40.5 & 6.44 & 5.68 & - \\
\hline V. anguistissima & 918 & 221 & - & 354 & 171 & 56.5 & 37.5 & 18.4 & 8.7 & 24.4 & - & - & - \\
\hline L. leucocephala & 909 & 291 & 89.0 & 349 & 214 & 48.0 & 120 & 14.6 & 6 & - & - & - & - \\
\hline S. sesban & - & 306 & 169 & 170 & 117 & 53.0 & - & - & - & - & - & - & - \\
\hline C. mopane & - & 140 & 190 & - & - & - & - & - & - & - & - & - & - \\
\hline M. oliefera & 860 & 268 & 157 & 200.8 & 137.9 & 56.3 & 108 & - & - & 7.7 & - & - & - \\
\hline P. scandens & 201 & 104 & - & 473 & 316 & - & - & - & - & - & - & - & 70 \\
\hline S. guianensis & 216 & 103 & - & 507 & 347 & - & - & - & - & - & - & - & 65 \\
\hline V. unguiculata & 156 & 162 & - & 359 & 252 & - & - & - & - & - & - & - & 51 \\
\hline \multicolumn{14}{|c|}{ Conventional protein sources } \\
\hline Soybean meal & 900 & 450 & 50.0 & - & - & 90.0 & 60.0 & - & - & - & - & - & - \\
\hline Sunflower meal & 930 & 455 & 117 & 356 & 344 & 160 & 200 & - & - & - & - & - & - \\
\hline
\end{tabular}


Table 3 The amino acid content of some of the selected common legumes $(\mathrm{g} / \mathrm{kg} \mathrm{DM})$

\begin{tabular}{|c|c|c|c|c|c|c|c|c|c|c|}
\hline Variable & Threonine & Glycine & Valine & Cysteine & Methionine & Isoleucine & Tyrosine & Phenylalanine & Lysine & Histidine \\
\hline \multicolumn{11}{|c|}{ Non-conventional legumes } \\
\hline$V$.nilotica & 6.2 & 6.8 & 7.3 & 4.4 & 2.6 & 5.6 & 5.3 & 6.8 & 8.4 & 2.8 \\
\hline V. karroo & 5.0 & 5.5 & 5.9 & 3.2 & 1.9 & 4.3 & 3.8 & 5.4 & 6.6 & 2.3 \\
\hline L. leucocephala & 12 & 13 & 14 & 2.0 & 4.6 & 14 & 13 & 15 & 18 & 5.4 \\
\hline G.sepium & 12 & - & 16 & 3.9 & 4.2 & 12 & 11 & 15 & 11 & 5.1 \\
\hline S. sesban & 9.9 & 10 & 11 & 0.5 & 3.7 & 9.2 & 6.9 & 11 & 13 & 4.4 \\
\hline C. mopane & 5.5 & 5.9 & 6.9 & 3.9 & 2.4 & 5.1 & 4.2 & 6.4 & 7.3 & 2.5 \\
\hline M. oliefera & - & - & - & - & 4.0 & - & - & - & 7.5 & - \\
\hline P. scandens & 10 & 14 & - & - & 3.5 & 8.8 & 5.0 & 9.4 & 9.4 & 4.3 \\
\hline S. guianensis & 8.5 & 13 & - & - & 3.2 & 7.8 & 4.6 & 8.8 & 8.1 & 3.8 \\
\hline V. unguiculata & 11 & 17 & - & - & 4.2 & 10 & 5.5 & 11 & 9.7 & 4.4 \\
\hline \multicolumn{11}{|c|}{ Conventional protein sources } \\
\hline Soybean meal & 4.0 & 4.5 & 5.5 & 1.0 & 1.4 & 1.5 & 4.2 & 4.9 & 6.8 & 3.0 \\
\hline Sunflower meal & 16 & - & 14 & - & 6.2 & 13 & - & 13 & 11 & 9.6 \\
\hline
\end{tabular}

Source: Piva (1992); Ravindran \& Blair (1992); Halimani et al. (2005); Khanyile et al. (2014); Mukumbo et al. (2014); Kambashi et al. (2016)<smiles>O=C(O)c1cc(O)c(O)c(I)c1</smiles>

Gallic acid

Hydrolysable polyphenolic<smiles>O=c1cc(-c2ccccc2)oc2ccccc12</smiles>

Flavone

Condensed polyphenolic

Figure 1 Structure of condensed and hydrolysable polyphenolics Source: Ashok \& Upadhayaya (2012) 
polyphenolics are dimers or oligomers of catechin, epicatechin or similar units (Ashok \& Upadhayaya, 2012). The structure of these units is joined by carbon-carbon bonds, which can be broken by hydrolysis (Kambashi et al. 2014). Mokoboki et al. (2005) defined condensed tannins as polymers of flavonol units most frequently linked at carbon (C) 4 - C8 or C4 - C6. Condensed polyphenolics have been identified as a major nutritional factor affecting productivity of pigs fed leaf meals from legume trees and shrubs. The most common condensed polyphenolic found in leguminous leaves is tannins (Ashok \& Upadhayaya. 2012). Vachellia species contain high amounts of polyphenolic compounds, there is a need to develop strategies to ameliorate their effects on pig performance if the species is to be used as a protein source in pig diets.

\section{Performance of pigs fed on leguminous leaf meals}

The performance of pigs offered different leaf meal-based diets is shown in Table 4. The response of pigs to incorporation of leguminous leaf meal cannot be generalised because it depends on different characteristics of chemical composition and physical properties of leaf meal including the ratio of the different components in the overall diet

Table 4 Performance of pigs fed leguminous species

\begin{tabular}{lccccc}
\hline \multirow{2}{*}{ Legume Species } & Inclusion level (g/kg DM) & \multicolumn{4}{c}{ Growth performance } \\
\cline { 3 - 6 } & & ADFI (kg/d) & ADG $\mathbf{~ k g ~ / d ) ~}$ & FCR & G:F ratio \\
\hline Vachellia tortilis & 50 & 3.08 & 0.860 & - & 0.368 \\
Vachellia tortilis & 100 & 2.78 & 0.853 & - & 0.341 \\
Vachellia tortilis & 150 & 3.02 & 0.559 & - & 0.329 \\
Vachellia tortilis & 200 & 2.35 & 0.442 & - & 0.308 \\
Vachellia tortilis & 250 & 2.03 & 0.387 & - & 0.324 \\
Leucaena leucocephala & 200 & 1.79 & 603 & 2.52 & - \\
Moringa Oliefera & 25 & 3.1 & 0.9 & 3.4 & - \\
Moringa Oliefera & 50 & 3.1 & 1.0 & 3.2 & - \\
Moringa Oliefera & 75 & 3.6 & 0.9 & 3.9 & - \\
Sechium edule & 400 & 96.07 & 1.8 & 5.74 & - \\
Vachellia karroo & 100 & 2.62 & $1080.4 \mathrm{~g} /$ day & 2.4 & - \\
Colophospermum mopane & 100 & 2.37 & $1003.6 \mathrm{~g} /$ day & 2.4 & - \\
Vachellia nilotica & 100 & 2.47 & $987.5 \mathrm{~g} /$ day & 2.5 & - \\
Psophocarpus scandens & $321 \mathrm{~g} /$ day & 1.88 & $515 \mathrm{~g} /$ day & 3.66 & - \\
Stylosanthes guianerisis & $232 \mathrm{~g} /$ day & 1.98 & $543 \mathrm{~g} /$ day & 3.67 & - \\
Vigna unguiculata & $214 \mathrm{~g} /$ day & 1.89 & $537 \mathrm{~g} /$ day & 3.55 & - \\
\hline
\end{tabular}

Source: Halimani et al. (2005); Khanyile et al. (2014); Mukumbo et al. (2014); Lalthansanga and Samanta (2015); Kambashi et al. (2016).

ADFI: average daily feed intake (kg/d DM); ADG: average daily gain (g BW/d); BW: body weight; G: F ratio: gain: feed ratio; FCR: Feed conversion ratio

The variation in average daily feed intake (ADFI), average daily gain (ADG), feed conversion ratio $(\mathrm{FCR})$ and gain: ratio $(\mathrm{G} / \mathrm{F})$ could be due to different leguminous species, stage of harvesting, harvesting method and pig genotypes used (Table 4). Maximum utilisation of leaf meals is limited because of the presence of polyphnolic compounds, which plays a major role in reduction in intake, reduced digestibility and lower efficiency (Bhat et al., 2013; Kambashi et al., 2016). The low FCR is driven by bitter and astringent taste from tannins.

Khanyile et al. (2014) reported that the maximum average daily feed intake and average daily gain were reached at $125 \pm 19.4$ and $137 \pm 12.1 \mathrm{~g} / \mathrm{kg} \mathrm{DM}$ of $V$. tortilis inclusion level, respectively. At high inclusion level (137 g/kg DM), leaf meal tends to negatively affect mucosal lining of the digestive tract (Table 4). High tannins bind protein, which in turn, causes reduction of protein digestibility and carbohydrates together with starch and fibers (Martens et al., 2013). The low intake and ADG has been attributed to the 
presence polyphenolics such as tannins in $V$. tortilis. It is, therefore, of interest to investigate the possible ways to neutralise undesired polyphnolics found in legume tree leaves.

\section{Physiological adaptation of pigs to leguminous leaf meals}

Polyphenolics such as tannins may reduce intake of forage legumes by decreasing palatability or by negatively reducing digestibility of nutrients (Barry et al., 1999). Astringency is the sensation caused by the formation of complexes between tannins and salivary glycoprotein. Astringency may increase salivation and reduce palatability (Makkar, 2003). Tannins have a number of detrimental biological effects (Mlambo et al., 2015). These effects include interference with pig growth, digestibility and metabolism (Yan \& Bennick, 1995). Pigs produce very limited tannin-binding salivary proline-rich protein and histatins as a coping mechanism that protect them from negative nutritional and health effects. Nonetheless, a retarded growth performance of pigs when fed high levels of leguminous leaves has been reported (Halimani et al., 2005; Khanyile et al., 2014). In addition, pigs have a limited ability to utilise tannin-rich feedstuff due to their physiological nature. It is because, unlike ruminants, they do not have bacteria, which counter the effects of tannins. To maximise the use of leguminous leaf meals as feedstuff for pigs, it is fundamental to develop strategies to improve their utilisation such as introduction of polyphenolic-binding agents.

\section{Inactivating polyphenolic -protein complexes}

Different methods have been used to inactivate detrimental and toxic effects of tannins to improve their nutritive value of feedstuffs. These methods include the use of binding agents (polyethylene glycol, polyvinylpyrrolidone, polyvinyl polypyrrolidone, acetic acid, and sodium hydroxide), heating, soaking in water and drying, wood ash, chopping and storage, urea, solid-state fermentation and use of enzymes (Bhat et al., 2013; Hlatini et al., 2016). The methods are commonly grouped into physical and chemical methods.

Common methods of physical treatments do not seem to be economically viable and are less effective due to intensive labour requirements and being time consuming. However, chopping of fresh leaves, water soaking, and then storage is a practical and economical method for smallholder farmers (Bhat et al., 2013). Several chemical methods have been evaluated (Kyarisiima et al., 2004; Ben Salem, 2005a; Ben Salem, 2005b). Chemical methods are associated with loss of nutrients and are expensive to resource-limited farmers. Use of tannin-binding agents such as PEG are gaining intrigue due to their effectiveness in binding with tannins. Polyethylene glycol has been identified as the most effective way of detoxifying legume tree leaves.

\section{Performance of pigs fed leguminous leaf meal treated with polyethylene glycol}

Polyethylene glycol is a non-nutritive synthetic polymer, an oligomer or polymer of ethylene oxide with a molecular mass below 20,000 g/mol (Makkar, 2003). Polyethylene glycols of different molecular weight are available commercially, and their molecular weight ranges from as little as 200 upwards. The chemical formula for PEG is (C2H4O) $n+1 \mathrm{H}_{2} \mathrm{O}$ (Henning, 2002) where " $n$ " represents the average number of oxethylene groups, and below $55^{\circ} \mathrm{C}$ it is a free-flowing white powder freely soluble in water. The PEG with higher molecular weight are available as free-flowing white powder (1500 and 4000) and creamy with flakes for the range 4000 to 8000 (Table 5) and is be preferred to others, because of its ability to bind tannins at near neutral $\mathrm{pH}$. The PEG is a good binder of protein than PVP for $\mathrm{pH} 3$ to 7.

Polyethylene glycol has the ability to dissolve many substances and the higher molecular weight of PEG is capable to solubilize water insoluble compounds (Kambashi et al., 2014). The most important physical property of PEG is its solubility in water, making it ideal for inclusion in leaf meals (Ben Salem et al., 2005b). Salem et al. (2000) reported that PEG has been used for fractional precipitation of properties. It is usually used as a substance to make proteins from ingested tannin containing feed to be available for utilisation by livestock. There is little information on the use of tannin-binding agent such as polyethylene glycol to overcome problems associated with reduced feed nutrient value, toxic effect and utilisation on pigs fed Vachellia leaf meal diets.

Hlatini et al. (2016) suggested that PEG with molecular weight of 4,000 is effective in preventing the binding of polyphenolics and protein from $V$. tortilis leaves. A minimum of $1.8 \mathrm{~g}$ PEG can completely reverse the binding effect of $1 \mathrm{~g}$ of tannins (Barry \& Foss, 1983). Makkar et al. (1995) suggested that strong binding of PEG with polyphenolics could also decrease the recovery of the PEG in faeces when PEG is incorporated into the tannin-rich feed to alleviate the adverse effects of tannins. The effect of tannins on eating activity of pigs, and interactions with PEG supplementation has not been reported. Oduguwa et al. (2007) reported that PEG (1 $\mathrm{g}$ and $10 \mathrm{~g} / \mathrm{kg} \mathrm{DM} \mathrm{+} 30 \mathrm{~g}$ of malted sorghum with $140 \mathrm{~g} / \mathrm{kg}$ polyphenolics) did not improve on the apparent amino acid digestibility and true amino acid digestibility. This could be associated with polyphenolic bound to PEG or other components such as fibre. On the other hand, Mansoori \& Acamovic (2009) 
determined that PEG improved protein digestibility, utilisation and reduced negative effect of tannins in the gastrointestinal tract of birds fed on high tannins feeds. Hlatini et al. (2016) reported an increase in average daily gain as the PEG inclusion level increased in $V$. tortilis based-diets.

Table 5 Mean \pm standard error of binding (measured as turbidity at $500 \mathrm{~nm}$ ) of polyethyleneglycols (PEG) of different molecular weights with tannins at $\mathrm{pH} 6,6^{*}$

\begin{tabular}{llllllllllllll}
\hline & \multicolumn{2}{c}{ TA } & \multicolumn{2}{c}{ QT } & \multicolumn{2}{c}{ Ab } & \multicolumn{2}{c}{ Dc } & \multicolumn{2}{c}{ Pr } & \multicolumn{3}{c}{ Gs } \\
\cline { 2 - 13 } & & & & & & & & & & & & & \\
PEG 2000 & 0.520 & 0.006 & 0.293 & 0.003 & 0.399 & 0.006 & 0.451 & 0.006 & 0.120 & 0.001 & 0.267 & 0.002 \\
PEG 4000 & 0.610 & 0.005 & 0.314 & 0.005 & 0.496 & 0.004 & 0.552 & 0.005 & 0.225 & 0.005 & 0.345 & 0.001 \\
PEG 600 & 0.605 & 0.004 & 0.293 & 0.009 & 0.501 & 0.010 & 0.528 & 0.006 & 0.234 & 0.007 & 0.340 & 0.004 \\
PEG 10000 & 0.592 & 0.002 & 0.290 & 0.004 & 0.525 & 0.005 & 0.560 & 0.005 & 0.240 & 0.005 & 0.328 & 0.008 \\
PEG 20000 & 0.613 & 0.005 & 0.303 & 0.002 & 0.558 & 0.004 & 0.532 & 0.006 & 0.225 & 0.004 & 0.358 & 0.005 \\
PEG 35000 & 0.600 & 0.005 & 0.287 & 0.010 & 0.542 & 0.010 & 0.501 & 0.005 & 0.242 & 0.002 & 0.339 & 0.010 \\
PEG compound & 0.632 & 0.004 & 0.310 & 0.005 & 0.513 & 0.005 & 0.578 & 0.006 & 0.258 & 0.002 & 0.352 & 0.006
\end{tabular}

Source: Makkar et al. (1995)

TA: tannic acid; QT: quebracho (Aspidosperma quebracho) tannins; Ab: Acioa barteri; Dc: Dichostachys cinerea; Pr: Piliostigma reticulatum; Gs: Guiera senegalensis.

*The assay used $100 \mathrm{ml}$ tannin solution $(2 \mathrm{mg} / \mathrm{ml})$ and $50 \mu \mathrm{PEG}(0.5 \mathrm{mg} / \mathrm{ml})$.

The PEG also increases the palatability of high polyphenolic forages thereby increasing their intake (Nsahlai et al., 2011; Ghandour et al., 2014). Yu et al. (1995) added PEG at a rate of $2 \mathrm{mg} / \mathrm{g}$ total condensed tannins to make most of protein available for utilisation. Detrimental effect in nutrition caused by polyphenolic compounds may not be completely reversed by application of PEG. However, the presence of PEG may increase astringency and appetite when low-tannin alternatives offer fewer nutrients than the high-tannin forage (Phengsavanh, 2013; Ghandour et al., 2014).

The information on effects of PEG supplementation on the performance of pigs fed leaf mealcontaining diets is scarcely documented. Rowan \& Lawrence (1986) studied growth, tissue deposition, and metabolism from growing pigs fed on rapeseed meal treated with different levels of PEG and copper, and they determined that PEG at $17 \mathrm{~g} / \mathrm{kg}$ DM significantly improved growth rate. Savage et al. (1980) reported the positive influence of micronization and polyethylene glycol on the nutritional value of brown sorghum for growing pigs.

Metabolites are undoubtedly the best practical predictor and it could be useful in preventing metabolic shortages together with damages in the animal (Ndou et al., 2015a). Hlatini \& Chimonyo (2016) reported that as the PEG inclusion level increased, albumin concentration increased at an increasing rate and had no effect on cholesterol, creatinine and uric acid concentrations to pigs fed on tannin-rich diet. Authors further observed a linear relationship between PEG inclusion level and globulin. Changes in the constituent compounds of blood when compared to normal values could be used to determine metabolic state together with feed quality. Moreover, blood biochemistry and body condition of pigs could help to predict status of energy, protein, glucose and early sign of metabolic disorders (Lim et al., 2013; Ndou et al., 2015a).

Serum protein, iron, and cholesterol are vital when identifying the nutrients profile of animals (Ndlovu et al., 2009). The acceptable levels of blood cholesterol indicate the health and safety of the leaf meal on pigs (Washington \& Van Hoosier, 2012). Blood cholesterol concentration could be reduced by the presence of polyphenolics in pig diets (Jansman, 1993), though no significant change was observed by Hlatini \& Chimonyo (2016). Reduction in iron and copper bioavailability was observed in pigs given polyphenolic rich feeds (Bravo et al., 2008). Khanyile et al. (2014) observed that Vachellia tortilis leaf meal diet did not influence the serum phosphorus and total protein concentration. There is little information concerning the effect of PEG treated leaf meal on blood metabolites from growing pigs. Moreover, there are few challenges of treating leaf meals with PEG compared to other methods.

There is a need to determine effect of PEG treated leaf meal on blood lipid profiles that may be of interest to pig nutritionists. Environmental contamination with nitrogen-containing products in manure is a topical issue in the tropics. Hlatini et al. (2017) reported that increasing levels of PEG resulted to an increase 
in serum iron concentration until it reached a plateau then it started to decrease. The Authors also observed a linear increase in nitrogen utilisation and retention with PEG inclusion.

The PEG may be utilized in different ways such as spraying leaves, oral dosage and mixed with diet (Ben Salem et al., 2000). Application of PEG by spraying the standing plants prior to utilisation requires a lot of labour and its time consuming, while mixing with diets is preferred. Oral dosage may include a slower onset of action, irritating and stressing to animals (Turner et al., 2011). Otherwise, spraying and oral dosage both requires a moderate technical skill accompanied with confidence. The use of PEG needs to be performed accurately, rapidly, and humanely in animals (Bhat et al., 2013). Application of PEG has been recommended however, the methods are either uneconomical and/or impractical under farmer management. There is little on the literature concerning the supplementation of PEG on leaf meal diets of pigs.

\section{Concluding remarks and further research}

Polyphenolic-containing feed sources such as trees and shrubs foliage and agro-industrial byproducts could be used to partially replace expensive commercial protein sources, because humans do not directly consume them. Leguminous leaves could be used as an alternative source to provide protein for pigs. However, these feed resources contain anti-nutritive factors that reduce their utilisation. Therefore, the response of pigs to low and moderate levels of polyethylene glycol on growth and metabolism needs to be explored. The use of PEG may assist in increasing protein and amino acid supply to meet nutrient requirements of animals. Mechanisms by which the PEG ameliorates the effects of in-feed tannins in different classes of livestock and how this is manifested in different gut segments need to be established. There is also the necessity to determine the digestibility and nitrogen balance of Vachellia leaf meal treated with graded levels of PEG in pigs. Due to anti-nutritive factors in leaf meals, pigs do not maximize utilization of leguminous leaves. This calls for research in optimizing the intake of protein through application of PEG. It is crucial to investigate the optimum inclusion level of PEG for performance of growing pigs and appraise the effect of PEG treated leaf meals on carcass characteristics and pork quality.

\section{Acknowledgements}

This review is part of the project that funded by National Research Foundation (102702) and competitive grant from University of KwaZulu Natal.

\section{Authors' contributions}

VAH did the layout and writing of first draft of the manuscript. CNC, TJZ and MC edited the layout and content of the manuscript.

\section{Conflicts of Interest Declaration}

There is no conflict of interest among the authors and funders of the project.

\section{References}

Abdulrazak, S.A., Orden, E. A., Ichinohe, T. \& Fujhara, T., 2000. Chemical composition, phenolic concentration and In vitro gas production characteristics of selected Acacia fruits and leaves. J. Anim. Sci. 7, 935-940.

Abule, E., Snyman, H.A. \& Smit, G. N., 2007. Rangeland evaluation in the middle: A wash valley of Ethiopia: II. Woody vegetation. J. Arid. Environ. 70, 272-292.

Ashok, P.K. \& Upadhyaya, K., 2012. Tannins are astringent. Anim. Feed Sci. Technol. 106, 3-19.

Barakat, N. A., Laudadio, V., Cazzato, E. \& Tufarelli, V., 2013. Potential contribution of Retama raetam (Forssk.) Webb \& Berthel as a forage shrub in Sinai, Egypt. Arid. Land. Res. Manag. 27, 257-271.

Barry, T. N., McNabb, W. C., 1999. The implications of condensed tannins on the nutritive value of temperate forages fed to ruminants. Br. J. Nutr. $81,263-272$.

Barry, T.N. \& Forss, D.A., 1983. The condensed tannin content of vegetative lotus pedunculatus, its regulation by fertiliser application, and effect upon protein solubility. J. Sci. Food Agric. 34, 1047-1056.

Ben Salem, H., Makkar, H.P.S., Nefzaoui, A., Hassayoun, L. \& Abidi, S., 2005a. Benefit from the association of small amounts of tanninrich shrub foliage (Acacia cyanophylla Lindl.) with soya bean meal given as supplements to Barbarine sheep fed on oaten hay. Anim. Feed Sci. Technol. 122, 173-186.

Ben Salem, H., Nefzaoui, A., Ben Salem, L. \& Tisserand, L.J., 2000. Deactivation of condensed tannins in Acacia cyanophylla Lindl.foliage by polyethylene glycol in feed blocks: Effect on feed intake, diet digestibility, nitrogen balance, microbial synthesis and growth by sheep. Livest. Prod. Sci. 64, 51-60.

Ben Salem, H., Saghrouni, L. \& Nefzaoui, A., 2005b. Attempts to deactivate tannins in fodder shrubs with physical and chemical treatments. Anim. Feed Sci. Technol. 122, 109-121.

Besharati, M. \& Taghizadeh, A., 2011. Effect of tannin-binding agents (polyethylene glycol and polyvinylpyrrolidone) supplementation on In Vitro gas production kinetics of some grape yield byproducts. Vet. Sci, 2011.

Bhat, K.T., Kannan, A., Singh, B. \& Sharma, P.O., 2013. Value addition of feed and fodder by alleviating the antinutritional effects of tannins. Agric. Res. 3, 189-206. 
Dube, J.S., Reed, J.D. \& Ndlovu, L.R., 2001. Proanthocyanidins and related phenolics in Acacia leaves of Southern Africa. Anim. Feed Sci. Technol. 91, 59-67.

Ferraz de Oliveira, M.I., Cancela d'Abreu, M. \& Freitas, A., 2008. The effect of polyethylene glycol (PEG) on protein output of free range Alentejano pigs. Proceedings of the $6^{\text {th }}$ international symposium Mediterranean pig, Capo d'Orlando, Messina.

Food \& Agriculture Organization of the United Nations (FAO), 1993. Indigenous multipurpose trees of Tanzania: uses and economic benefits for people. Rome.

Ghandour, M.M.A., Fayed, A.M., Abdul-Aziz, G.M. \& Hanafy, M.A., 2014. Effect of using polyethylene glycol or sodium bentonite on performance of sheep fed Acacia saligna. World. Appl. Sci. J. 32, 2309-2316.

Halimani, T.E., Dzama, K., Chimonyo, M. \& Bhebhe, E., 2005b. Use of leguminous leaf meals in smallholder pig production in Zimbabwe. African Crop Science Conference Proceedings, 7, 579-582.

Halimani, T.E., Ndlovu, L.R., Dzama, K., Chimonyo, M. \& Miller, B.G., 2007. Metabolic response of pigs supplemented with incremental levels of leguminous Acacia karroo, Acacia nilotica and Colophospermum mopane leaf meals. Livest. Res. Rural. Dev. 19,187.

Halimani, T.E., Ndlovu, L.R., Dzama, K., Chimonyo, M., Miller, B.G., 2005a. Growth performance of pigs fed on diets containing Acacia karroo, Acacia nilotica and Colophosperamum mopane leaf meals. Anim. Sci. 81, 39-45.

Heuze', V., Tran, G., 2011. Umbrella thorn (Acacia tortilis). Feedipedia.org. A project by INRA, CIRAD, AFZ and FAO. http://. http://dx.doi.org/10.1590/S1517-83822012000100010l.

Hlatini, V. A. \& Chimonyo, M., 2016. Nutritionally-related blood metabolites and liver enzymes in growing pigs fed on Acacia tortilis treated with polyethylene glycol. Livest. Sci.187, 158-161.

Hlatini, V. A., Khanyile, M., Zindove, T. \& Chimonyo, M., 2016. Feed intake and growth performance of growing pigs fed on Acacia tortilis leaf meal treated with polyethylene glycol. Trop. Anim. Health. Prod. 48, 585-591.

Hlatini, V. A., Zindove, T. J. \& Chimonyo, M., 2017. The influence of polyethylene glycol inclusion in Vachellia tortilis leaf meal on nitrogen balance in growing pigs. S. Afr. J. Anim. Sci. 47, 298-306.

Jansman, A.J.M., 1993. Tannins in faba beans (Vicia faba L.) - anti-nutritional properties in monogastric animals. PhD. Thesis, Wageningen (the Netherlands).

Kambashi, B., Kalala, G., Dochain, D., Mafwila, J., Rollin, X., Boudry, C., Picron, P. \& Bindelle, J., 2016. Nutritive value of three tropical forage legumes and their influence on growth performance, carcass traits and organ weights of pigs. Trop. Anim. Health. Prod. 48, 1165-1173.

Kambashi, B., Picron, P., Boudry, C., Thewis, A., Kiatoko, H. \& Bindelle, J., 2014. Nutritive value of tropical forage plants fed to pigs in the Western provinces of the Democratic Republic of the Congo. Anim. Feed Sci. Technol. 191, 4756.

Karunajeewa, H., ljagbuji, E.G. \& Reece, R.L., 1990. Effect of dietary levels of rapeseed meal and polyethylene on the performance of male broiler chickens. Br. Poult. Sci. 31, 545-555.

Khanyile, M., Ndou, S.P. \& Chimonyo, M., 2014. Influence of Acacia tortilis leaf meal-based diets on growth performance of pigs. Livest. Sci. 167, 211-218.

Kraus, T.E.C., Zasoski, R.J., Dahlgren, R.A., Horwath, R.W. \& Preston, C.M., 2004. Carbon and nitrogen dynamics in a forest soil amended with purified tannins from different plant species. Soil. Biol. Biochem. 36, 309-321.

Lalthansanga, J. \& Samanta, A. K., 2015. Effect of feeding chayote (Sechium edule) meal on growth performance and nutrient utilization in indigenous pig (Zovawk) of Mizoram. Vet. World. 8, 918-923.

Lim, C, K., Penesyan, A, Hassan, K.A., Loper, E.J. \& Paulsen, T.I., 2013. Effect of tannic acid on the transcriptome of the soil bacterium Pseudomonas protegens Pf-5. J. Appl. Environ. Microbiol. 79, 3141-3145.

Makkar, H.P.S., 2003. Effects and fate of tannins in ruminant animals, adaptation to tannins and strategies to overcome detrimental effects of feeding tannin rich feeds. Small Rumin. Res. 49, 241-256.

Makkar, H.P.S., Blümmel, M. \& Becker, K., 1995. Formation of complexes between polyvinyl pyrrolidone and polyethylene glycol with tannins and their implications in gas production and true digestibility In vitro techniques. Br. J. Nutr. 73. 897-913.

Mansoori, B. \& Acamovic, T., 2009. Influence of tannic acid and polyethylene glycol on the excretion and digestibility of amino acids in gelatin-fed broilers. Br. Poult. Sci. 50, 199-206.

Mapiye, C., Chimonyo, M., Marufu, M.C. \& Dzama, K., 2011. Utility of Acacia karroo for beef production in Southern African smallholder farming systems: A review. Anim. Feed. Sci. Technol. 164, 135-146.

Martens, S.D., Tiemann, T.T., Bindelle, J., Peters, M. \& Lascano, C.E., 2013. Alternative plant protein sources for pigs and chickens in the tropics-nutritional value and constraints: a review. J. Agr. Rural. Dev. Trop. 113, 101-123.

Medugu, C.I., Saleh,B., Igwebuike, J.U. \& Ndirmbita, R.L., 2012. Strategies to improve the utilization of tannin-rich feed materials by poultry, Int. J. Poult. Sci. 11, 417-423.

Min, B.R., Barry, T.N., Attwood, G.T. \& McNabb, W.C., 2003. The effect of condensed tannins on the nutritional and health of ruminants fed fresh temperate forage: a review. Anim. Feed Sci. Technol. 106, 3-19.

Min, B.R., Hart, S.P., 2003. Tannins for suppression of internal parasites. J. Animal. Sci. 81,102- 109.

Mlambo, V., Marume, U., \& Gajana, C. S., 2015. Utility of the browser's behavioural and physiological strategies in coping with dietary tannins: Are exogenous tannin-inactivating treatments necessary? S. Afr. J. Anim. Sci. 45, 441-451.

Mlambo, V., Sikosana, J. L.N., Mould, F. L., Smith, T., Owen, E. \& Mueller-Harvey, I., 2007. The effectiveness of adapted rumen fluid versus Peg to ferment tannin-containing substrates In vitro. Anim. Feed Sci. Technol. 136, 128-136.

Mokoboki, H.K., Ndlovu, L.R. \& Malatje, M.M., 2005. "Intake and relative palatability indices of Acacia species fed to sheep and goats." Agrofor. Syst. 81, 31-35. 
Mokoboki, K. H., Malatje, M., Ng'ambi, W. J. \& Ndlovu, R. L., 2013. Short communication: The use of polyethylene glycol in the diagnosis of polyphenolics in the foliage of Acacia species. Asian Int. J. Life Sc. 9, 103-113.

Mueller-Harvey, I., 2006. Review unraveling the conundrum of tannins in animal nutrition and health. J. Sci. Food Agric. 86, 2010-2037.

Mukumbo, F.E., Maphosa, V., Hugo, A., Nkukwana, T.T., Mabusela, T.P. \& Muchenje V., 2014. Effect of Moringa oleifera leaf meal on finisher pig growth performance, meat quality, shelf life and fatty acid composition of pork. S. Afr. J. Anim. Sci. 44, 388-400.

Munyati, C., Economon, E.B. \& Malahlela, O.E., 2013. Effect of canopy cover and canopy background variables on spectral profiles of savanna rangeland bush encroachment species based on selected Acacia species (mellifera, tortilis, karroo) and Dichrostachys cinerea at Mokopane, South Africa. J. Arid. Environ. 94, 121-126.

Naumann, H.D., Tedeschi, L.O., Zeller, W.E. and Huntley, N.F., 2017. The role of condensed tannins in ruminant animal production: advances, limitations and future directions. Revista Brasileira de Zootecnia, 46(12), pp.929-949.

Ndlovu, T., Chimonyo, M., Okoh, A.I., Muchenje, V., Dzama, K., Dube, S. \& Raats, J.G., 2009. A comparison of nutritionally-related blood metabolites among Nguni, Bonsmara and Angus steers rose on sweet-veld. Vet. J. 179, 273-281.

Ndou, S. P., Khanyile, M. \& Chimonyo, M., 2015. Growth performance and nutrition-related serum metabolites in growing pigs fed on Acacia Tortilis leaf meal. Livest. Sci. 182, 22-27.

NFTA, 1991. NFT Highlight. A quick guide to useful nitrogen fixing trees from around the world. Acacia tortilis: fodder trees for desert sands.

Nsahlai, I.V., Fon, F.N. \& Basha, N.A.D., 2011. The effect of tannin with and without polyethylene glycol on In vitro gas production and microbial enzyme activity. S. Afr. J. Anim. Sci. 41, 337-344.

Nyamukanza, C.C. \& Scogings, P.F., 2008. Sprout selection and performance of goats fed Acacia karroo coppices in the False Thornveld of the Eastern Cape. S. Afr. J. Anim. Sci. 38, 83-90.

O'Connor, T.G., Puttick, J.R. \& Hoffman, M.T., 2014. Bush encroachment in southern Africa: changes and causes. Afr. J. Range. Forage. Sci. 31, 67-88.

Oduguwa, O.O., Pirgozliev, V. \& Acamovic, T., 2007. Energy metabolisability and digestibility of amoni acids by broilers fed on malted sorghum sprouts supplemented with polyethylene glycol, charcoal, phytase and xylanase. Br. Poult. Sci. 48, 55-63.

Orwa C., Mutua, A., Kindt, R., Jamnadass, R. \& Anthony, S., 2009. Agroforestree database: a tree reference and selection guide version 4.0. J. Pharmacogn. Phytochem. 1,45-50.

Pathak, K.A., Dutta, N., Banerjee, S.P., Pattanaik, K. A. \& Sharma, K., 2013. Influence of dietary supplementation of condensed tannins through leaf meal mixture on intake, nutrient utilization and performance of Haemonchus contortus infected sheep Asian-Australas. J. Anim. Sci. 26, 1446-1458.

Phengsavanh, P., 2013. Forage legumes as feed for pigs in smallholder production systems in the North of Lao PDR, PhD thesis, Swedish University of Agricultural Sciences, Uppsala Sweden.

Piva, G., 1992. Nutritional value of sunflower seed and sunflower meal for livestock animal. In: Proceedings of the 13th International Sunflower Conference. pp. 1611-1625.

Ravindran, V., \& Blair, R., 1992. Feed resources for poultry production in Asia and the Pacific. II. Plant protein sources. Worlds. Poult. Sci. J. 48, 205-231.

Rowan, G. \& Lawrence, T.L.J., 1986. Growth, tissue deposition and metabolism studies in growing pigs given low glucosinodale rapeseed meal diets containing different amount of copper and polyethylene glycol. J. Agric. Sci. $107,505-513$

Rubanza, K.D.C., Shem, N. M., Ichinole, T. \& Fujihara, T., 2006. Polyphenolics and mineral composition of selected browse tree species leaves native to north-western Tanzania traditional fodder banks. J. Food. Agric. Environ. 4, 328-332.

Saeidi, F., Houshmand, M., Parsaei, S., \& Zarrin, M., 2017. Potential of oak acorn with and without polyethylene glycol as an alternative to corn in broiler diets. S. Afr. J. Anim. Sci. 47, no 6.

Salem, A.Z.M., Salem, M.Z.M., El-Adawy, M.M. \& Robinson, P.H., 2005. Nutritive evaluations of some browse tree foliages during the dry: Secindar compounds, feed intake and In vivo digestibility in sheep and goats. Anim. Feed Sci. Technol. 127, 251-267.

Savage, G.P., Smith, W.C. \& Briggs, P.A., 1980. A note on the influence of micronization and polyethylene glycol on the nutritional value of brown sorghum for growing pigs. Anim. Sci. 30, 157-160.

Scogings, P. F., Dziba, L. E. \& Gordon, I. J., 2004. Leaf chemistry of woody plants in relation to season, canopy retention and goat browsing in a semiarid subtropical savanna. Aust. J. Ecol. 29, 278-286.

Silanikove, N., Perevolotsky, A. \& Provenza, D. F., 2001. Use of tannin-binding chemicals to assay for tannins and their negative post-ingestive effects in ruminants. Anim. Feed Sci. Technol. 91, 69-81.

Solomon, T.B. \& Mlambo, V., 2010. Encroachment of Acacia brevispica and Acacia drepanolobium in Semi-arid rangelands of Ethiopia and their influence on Sub-Canopy grasses. Res. J. Bot. 5, 1-13.

Tefera, S., Mlambo, V., Dlamini, B.J., Dlamini, A.M., Koralagam, K.D.N. \& Mould, F.L., 2008. Chemical composition and in vitro ruminal fermentation of common tree forages in the semi-arid rangelands of Swaziland. Anim. Feed Sci. Technol. 142, 99-110.

Tufarelli, V., Casalino, E., D'Alessandro, A. G. \& Laudadio, V., 2017. Dietary Phenolic Compounds: Biochemistry, Metabolism and Significance in Animal and Human Health. Curr. Drug. Metab. 18, DOI: $10.2174 / 1389200218666170925124004$.

Turner, P.V., Brabb, T., Pekow, C. \& Vasbinder, M.A., 2011.PMCID, PMC3189662 Administration of substances to laboratory animals, Routes of administration and factors to consider. J. Am. Assoc. Lab. Anim. 50, 600-613. 
Wahbi, J., Kaouther, M., Lamia, H., Mohsen, H. \& Larbi, M.K., 2013. Acacia tortilis (Forsk) Hayne subsp raddiana (Savi) in North African pseudo-savanna: Morphological variability and seed characteristics. Afr. J. Agric. Res. 8, 24822492.

Ward D., Hoffman, M.T. \& Collocott, S.J., 2014. A century of woody plant encroachment in the dry Kimberley savanna of South Africa. Afr. J. Range. Forage. Sci. 31, 107-121.

Washington, I.M. \& Hoosier, G.V., 2012. Clinical biochemistry and hematology. In Suckow M.A., Stevens, K.A., Wilson, R.P (authors). The Laboratory Rabbit, Guinea Pig, Hamster, and Other Rodents. Academic Press pp. 57-116.

Wina, E., Tangendjaja, B. \& Susana, I.W.R., 2005. "Effects of chopping, and soaking in water, hydrochloric acidic and calcium hydroxide solutions on the nutritional value of Acacia villosa for goats." Anim. Feed Sci. Technol. 122, 79-92.

Woyengo, T. A., Beltranena, E. \& Zijlstra, R. T., 2014. Non-ruminant nutrition symposium: controlling feed cost by including alternative ingredients into pig diets: a review. J. Anim. Sci. 92, 1293-1305.

Yan, Q., \& Bennick, A., 1995. Identification of histatins as tannin-binding proteins in human saliva. Biochemical Journal, 311, 341-347.

Yu, F., Moughan, P.J., Barry, T.N. \& McNabb, W.C., 1996. The effect of condensed tannins from heated and unheated cottonseed on the ileal digestibility of amino acids for the growing rat and pig. Br. J. Nutr. 76, 359-371. 